\title{
Elevated geothermal surface heat flow in the Amundsen Sea Embayment, West Antarctica
}

\author{
R. Dziadek ${ }^{\mathrm{a}, *}, \mathrm{~K}$ Gohl ${ }^{\mathrm{a}}$, N. Kaul ${ }^{\mathrm{b}}$, Science Team of Expedition PS104 ${ }^{1}$ \\ a Alfred Wegener Institute - Helmholtz Centre for Polar and Marine Research, Am Alten Hafen 26, 27568 Bremerhaven, Germany \\ ${ }^{\mathrm{b}}$ University of Bremen, Dept. of Geosciences, Klagenfurter Str. 2-4, 28359 Bremen, Germany
}

\section{A R T I C L E I N F O}

\section{Article history:}

Received 9 June 2018

Received in revised form 11 October 2018

Accepted 4 November 2018

Available online 6 December 2018

Editor: J.-P. Avouac

\section{Keywords:}

skin depth for geothermal gradients

spatial variation of geothermal heat flow on small scales

in situ temperature measurements

geotherm transition

\begin{abstract}
A B S T R A C T
The thermal state of polar continental crust plays a crucial role for understanding the stability and thickness of large ice sheets, the visco-elastic response of the solid Earth due to unloading when large ice caps melt and, in turn, the accuracy of future sea-level rise prediction. Various studies demonstrate the need for precise measurements and estimation of geothermal heat flow (GHF) in Antarctica for better constrained boundary conditions to enhance the ice sheet model performance. This study provides ground-truth for regional indirect GHF estimates in the Amundsen Sea Embayment, which is part of the West Antarctic Rift System, by presenting in situ temperature measurements in continental shelf sediments. Our results show regionally elevated and heterogeneous GHF (mean of $65 \mathrm{~mW} \mathrm{~m}^{-2}$ ) in the Amundsen Sea Embayment. Considering thermal blanketing effects, induced by inflow of warmer water and sedimentary processes, the estimated GHF ranges between $65 \mathrm{~mW} \mathrm{~m}^{-2}$ and $95 \mathrm{~mW} \mathrm{~m}^{-2}$.
\end{abstract}

(c) 2018 Elsevier B.V. All rights reserved.

\section{Introduction}

The Amundsen Sea Embayment is part of the West Antarctic Rift System (WARS, Fig. 1), which is the second largest continental rift system on earth (LeMasurier, 2008), and a key study area for GHF. Young, continental rift systems are regions with significantly elevated GHF (Morgan, 1983), because the transient thermal perturbation to the lithosphere caused by rifting requires $\sim 100$ myrs to reach long term thermal equilibrium (McKenzie, 1978; Jaupart and Mareschal, 2007). GHF strongly influences ice flow rates, basal friction, deformation rates, and/or hydrological systems, which in turn control ice-bed coupling, and therefore the height and dynamics of ice sheets (Hughes, 2009). Over recent years several studies adopted different geophysical approaches to estimate GHF from local (in situ) to broader scales (regional to continental) with in some cases large differences in their results (Fig. 1). All these studies have found, that GHF might be higher and spatially more variable than expected in previous decades (e.g. Llubes et al., 2006). The discovery of numerous subglacial lakes (Siegert and Dowdeswell, 1996), which can provide additional constraints on the basal thermal state of the ice sheet, is a strong argument for highly variable GHF (Llubes et al., 2006).

\footnotetext{
* Corresponding author.

E-mail address: ricarda.dziadek@awi.de (R. Dziadek).

1 The list of authors appears in Appendix A.
}

Basal ice sheet temperatures are controlled by a basal heat gradient (Siegert and Dowdeswell, 1996) in addition to frictional heat generated from ice deformation and basal sliding. The basal heat gradient is the sum of heat produced from basal sliding and geothermal heat flow (Siegert, 2000). Subglacial lakes where therefore correlated to a localized and moderate $\left(50 \mathrm{~mW} \mathrm{~m}^{-2}\right)$ to high $\left(80 \mathrm{~mW} \mathrm{~m}^{-2}\right.$; > $200 \mathrm{~mW} \mathrm{~m}^{-2}$ ) GHF (Siegert and Dowdeswell, 1996; Llubes et al., 2006; Fisher et al., 2015). Fisher et al. (2015) measured in situ temperature gradients and thermal conductivities at Subglacial Lake Whillans and estimated a GHF of $285 \pm$ $80 \mathrm{~mW} \mathrm{~m}^{-2}$. Begeman et al., 2017 followed their methods, deployed the temperature gradient probe $100 \mathrm{~km}$ away from SLW near the grounding zone of the Whillans Ice Stream and found a GHF of $88 \pm 7 \mathrm{~mW} \mathrm{~m}^{-2}$. They explain the spatial variability by shallow magmatic intrusions or the advection of heat by crustal fluids. A couple of months earlier Seroussi et al. (2017) had concluded that locally high GHF $\left(\geq 150 \mathrm{~mW} \mathrm{~m}^{-2}\right.$ ) below the Whillans Ice Stream was required to reproduce the observed subglacial lakes in an ice sheet model. Correlating GHF to the underlying geology (magmatic and tectonic history) is therefore vital to understand its distribution, in particular, when continental rifts such as the WARS underlie the ice sheet (Dalziel and Lawver, 2001). The coverage of in situ measurements in Antarctica is poor compared to other continents on Earth (Davies, 2013), because most areas are shielded by ice and difficult to access. This calls for a need to turn towards other methods to estimate heat flow on broader scales. 

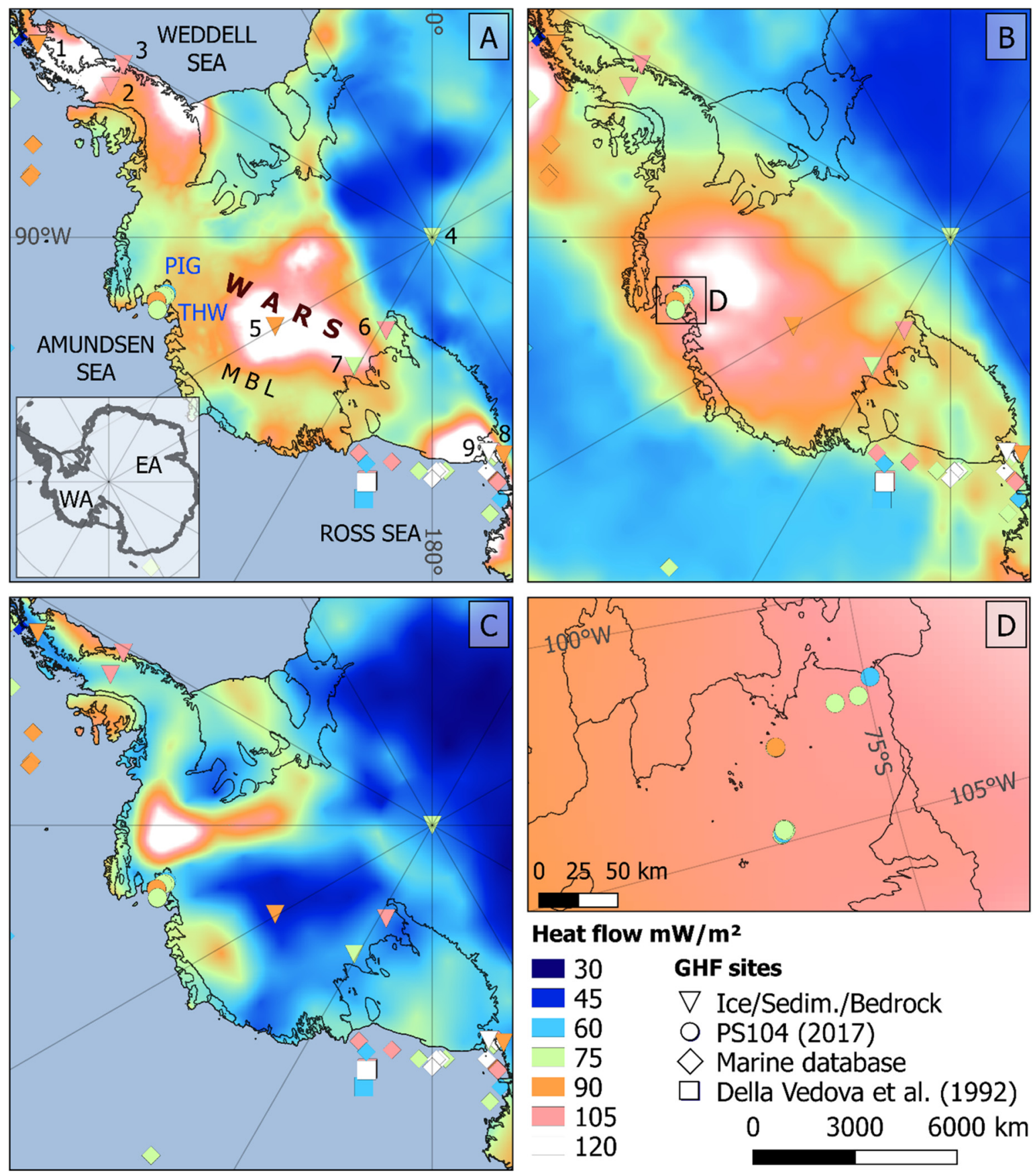

\section{Heat flow $\mathrm{mW} / \mathrm{m}^{2}$}

\section{- 30 GHF sites}

45

60

$\nabla$ Ice/Sedim./Bedrock

PS104 (2017)

75

$\diamond$ Marine database

90

105

120

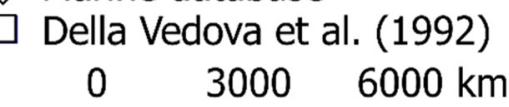

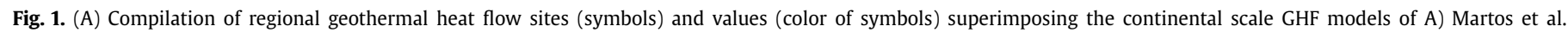

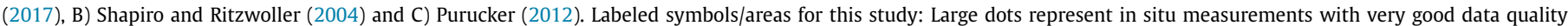

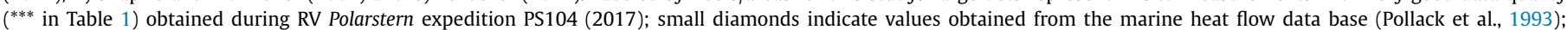

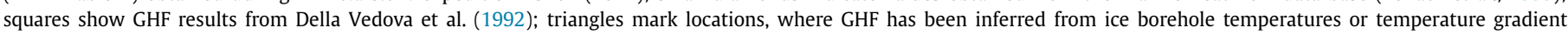

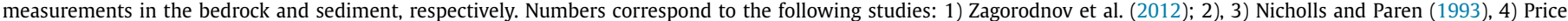

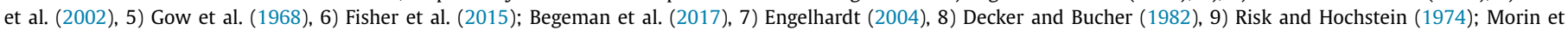
al. (2010). MBL - Marie Byrd Land; PIG - Pine Island Glacier; THW - Thwaites Glacier. See Fig. 3 and Fig. 4 for details.

Burton-Johnson et al. (2017) estimate regional scale GHF from radiogenic heat production and found high GHF $\left(81 \mathrm{~mW} \mathrm{~m}^{-2}\right)$ in the east and south of the Antarctic Peninsula (AP), where silicic rocks predominate, and $67 \mathrm{~mW} \mathrm{~m}^{-2}$ in the west and north of the Antarctic Peninsula, where volcanic arc and quartzose sediments are dominant. They state further that crustal thermal models must utilize a heterogeneous upper crust especially with respect to radioactive heat production. Old and thick sedimentary basins in particular could increase GHF significantly by the accumulation of radiogenic heat producing (RHP) elements. Schroeder et al. (2014) use radar echograms to estimate the pattern of basal melting and geothermal heat flow in the Thwaites Glacier catchment within the WAIS, which correlates locally well with the continental scale GHF models of Shapiro and Ritzwoller (2004). Other community-wide accepted studies (Fig. 1) use different methods, i.e. mainly seismic velocity models as regional indicators and Curie-depth analysis of magnetic anomaly data to estimate GHF (Fox Maule et al., 2005; Purucker, 2012; Martos et al., 2017). Overall the results do exhibit similarities in general tendencies, but vary significantly in regional comparison. Rogozhina et al. (2012) demonstrated in dif- 
Table 1

Summary of in situ temperature sites and estimated geothermal heat flow.

\begin{tabular}{|c|c|c|c|c|c|c|c|c|c|c|}
\hline \multirow{2}{*}{$\begin{array}{l}\text { Station } \\
\text { ID } \\
\text { HF1701 }\end{array}$} & \multirow{2}{*}{$\begin{array}{l}\text { Lat } \\
\left.\text { [DD.xxx }{ }^{\circ} \mathrm{S}\right] \\
-74.931\end{array}$} & \multirow{2}{*}{$\begin{array}{l}\text { Lon } \\
{\left[\mathrm{DD} \cdot \mathrm{xxx}{ }^{\circ} \mathrm{W}\right]} \\
-101.556\end{array}$} & \multirow{2}{*}{$\begin{array}{l}\text { Date } \\
\text { [dd.mm.yy] }\end{array}$} & \multirow{2}{*}{$\begin{array}{l}\text { Instrument } \\
\text { GRAVITY }\end{array}$} & \multicolumn{2}{|c|}{$\begin{array}{l}\text { Gradient } \pm 2 \sigma \\
{\left[{ }^{\circ} \mathrm{C} \mathrm{km}^{-1}\right]}\end{array}$} & \multicolumn{2}{|c|}{$\begin{array}{l}\text { Heat flow } \pm 2 \sigma \\
{\left[\mathrm{mW} \mathrm{m}^{-2}\right]}\end{array}$} & \multirow{2}{*}{ 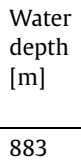 } & \multirow{2}{*}{$\begin{array}{l}\text { Data quality } \\
\text { *poor } \\
\text { ** good } \\
\text { ***very good } \\
\text { ** }\end{array}$} \\
\hline & & & & & 26.2 & \pm 1.3 & 30.8 & \pm 1.5 & & \\
\hline HF1702 & -74.868 & -100.711 & 18.02 .17 & GRAVITY & 30.2 & \pm 2.4 & 35.4 & \pm 2.8 & 700 & $* *$ \\
\hline HF1703 & -74.986 & -101.869 & 18.02 .17 & GRAVITY & 41.3 & \pm 12.1 & 48.5 & \pm 14.2 & 980 & $*$ \\
\hline HF1704 & -75.031 & -101.939 & 18.02.17 & PROBE $4 \mathrm{~m}$ & 44.6 & \pm 7 & 52.4 & \pm 8.2 & 950 & $* * *$ \\
\hline HF1705 & -74.942 & -102.295 & 18.02 .17 & PROBE $4 \mathrm{~m}$ & 51.9 & \pm 7.2 & 60.9 & \pm 8.4 & 936 & $* * *$ \\
\hline HF1706 & -74.684 & -101.622 & 19.02.17 & GRAVITY & 94.9 & - & 111.4 & - & 345 & $*$ \\
\hline HF1707 & -74.684 & -101.625 & 19.02.17 & GRAVITY & - & - & - & - & 340 & \\
\hline HF1708 & -74.838 & -101.044 & 20.02 .17 & GRAVITY & 35.6 & - & 41.7 & - & 530 & * \\
\hline HF1709 & -74.549 & -102.586 & 20.02 .17 & GRAVITY & 25.2 & - & 29.5 & - & 600 & * \\
\hline HF1710 & -74.803 & -102.344 & 20.02 .17 & PROBE $4 \mathrm{~m}$ & 55 & \pm 3.7 & 64.5 & \pm 4.3 & 1000 & $* * *$ \\
\hline HF1711 & -74.359 & -104.747 & 20.02 .17 & PROBE $8 \mathrm{~m}$ & 55.8 & \pm 3.7 & 65.4 & \pm 4.4 & 1384 & $* * *$ \\
\hline HF1712 & -74.355 & -104.757 & 21.02 .17 & PROBE $8 \mathrm{~m}$ & 51 & \pm 2.7 & 59.8 & \pm 3.2 & 1387 & $* * *$ \\
\hline HF1713 & -72.768 & -107.092 & 24.02 .17 & GRAVITY & - & - & - & - & 707 & \\
\hline HF1714 & -72.891 & -104.099 & 01.03 .17 & PROBE $4 \mathrm{~m}$ & 92.1 & - & 108.1 & - & 490 & $*$ \\
\hline HF1715 & -74.416 & -102.990 & 02.03.17 & PROBE $8 \mathrm{~m}$ & - & - & - & - & 744 & \\
\hline HF1716 & -74.417 & -103.005 & 02.03 .17 & PROBE $8 \mathrm{~m}$ & 97.6 & - & 114.6 & - & 740 & $* *$ \\
\hline HF1717 & -74.416 & -103.001 & 02.03.17 & PROBE $8 \mathrm{~m}$ & 54 & \pm 4.7 & 63.3 & \pm 5.5 & 740 & $* * *$ \\
\hline HF1718 & -74.415 & -102.998 & 02.03 .17 & PROBE $8 \mathrm{~m}$ & 57.5 & \pm 4.9 & 67.5 & \pm 5.7 & 740 & $* * *$ \\
\hline HF1719 & -74.414 & -102.995 & 02.03 .17 & PROBE $8 \mathrm{~m}$ & 57.4 & \pm 4 & 67.4 & \pm 4.7 & 737 & $* * *$ \\
\hline HF1720 & -74.413 & -102.992 & 02.03.17 & PROBE $8 \mathrm{~m}$ & 59.4 & \pm 0.9 & 69.7 & \pm 1.1 & 740 & $* * *$ \\
\hline HF1721 & -74.412 & -102.988 & 02.03.17 & PROBE $8 \mathrm{~m}$ & 57.7 & \pm 4 & 67.7 & \pm 4.7 & 735 & $* * *$ \\
\hline HF1722 & -74.416 & -102.987 & 02.03 .17 & PROBE $8 \mathrm{~m}$ & 65.4 & \pm 0.7 & 76.7 & \pm 0.8 & 735 & $* * *$ \\
\hline HF1723 & -74.330 & -104.822 & 03.03.17 & PROBE $8 \mathrm{~m}$ & 62.1 & \pm 0.3 & 72.9 & \pm 0.3 & 1400 & $* * *$ \\
\hline HF1724 & -74.331 & -104.820 & 03.03.17 & PROBE $8 \mathrm{~m}$ & 57.5 & \pm 1.4 & 67.5 & \pm 1.7 & 1395 & $* * *$ \\
\hline HF1725 & -74.340 & -104.799 & 03.03.17 & PROBE $8 \mathrm{~m}$ & 49.4 & \pm 8.7 & 58 & \pm 10.2 & 1388 & $* * *$ \\
\hline HF1726 & -74.349 & -104.721 & 03.03.17 & PROBE $8 \mathrm{~m}$ & 51.4 & \pm 4.4 & 60.3 & \pm 5.2 & 1405 & $* * *$ \\
\hline HF1727 & -74.355 & -104.760 & 03.03.17 & PROBE $8 \mathrm{~m}$ & 54.1 & \pm 1.9 & 63.5 & \pm 2.3 & 1385 & $* * *$ \\
\hline HF1728 & -74.349 & -104.737 & 04.03 .17 & PROBE $8 \mathrm{~m}$ & 51.2 & \pm 2.5 & 60.1 & \pm 2.9 & 1453 & $* * *$ \\
\hline HF1729 & -73.297 & -112.330 & 10.03.17 & PROBE $4 \mathrm{~m}$ & 8.60 & - & 10.1 & - & 483 & $*$ \\
\hline
\end{tabular}

ferent model tests for Greenland Ice Sheet evolution against GHF reproducibility, that all of the GHF models failed to fit the observations and that simulations with a simple spatial uniform GHF forcing gives a considerably better fit. The ice sheet modeling community (e.g. Golledge et al., 2015) repeatedly outlined the importance of better constrained thermal boundary conditions to enhance the accuracy of ice sheet model performance for future sea level rise predictions. Moreover, Barletta et al. (2018) demonstrate that the solid-Earth deformation exerts an important control on the possibility of future West Antarctic Ice Sheet (WAIS) collapse. The visco-elastic response of a low-strength lithosphere due to unloading by a WAIS collapse limits the ice retreat in the Amundsen Sea Embayment (ASE) on time scales of several millennia, whereas a stiffer lithosphere would yield a collapse due to slower response. Lithospheric elastic thickness and strength are controlled primarily by temperature (Hyndman et al., 2009). Hence in situ temperature measurements, albeit near surface, will help understand the behavior of the anomalously thin crust in West Antarctica (Chaput et al., 2014; Damiani et al., 2014) that exhibits reduced effective elastic lithospheric thickness ( $0 \mathrm{~km}<T_{e}<20 \mathrm{~km}$ ) (Kalberg et al., 2015; Chen et al., 2017). Our objective is an assessment of GHF distributions in the Amundsen Sea Embayment derived from in situ temperature measurements conducted during RV Polarstern expedition PS104 in early 2017. We analytically demonstrate that temperature variations are likely induced by inflow of warm Circumpolar Deep Water (CDW) at the sea floor and do not extend beyond depths of $4 \mathrm{~m}$ below sea floor in the sediment nor disturb our measurements. Ground-truthing for GHF is highly important since published results vary significantly and exhibit an important boundary condition for past and present Glacial Isostatic Adjustment, ice sheet models, and future sea level rise predictions.

\section{Data and methods}

\subsection{In situ temperature measurements}

In situ temperature measurements were conducted at 29 stations during RV Polarstern expedition PS104 in February and March 2017. We used Miniaturized Temperature Loggers (MTL) with $0.001 \mathrm{~K}$ resolution and $0.1 \mathrm{~K}$ precision (Pfender and Villinger, 2002), which were mounted on a MTL sensor rod or attached to a gravity corer, both with varying lengths between $4 \mathrm{~m}$ and $10 \mathrm{~m}$. Prior to deployment, the MTL were calibrated for absolute temperatures with the ship's SBE911plus CTD (conductivity, temperature, and depth) in the water column. After calibration, the offset between MTL and CTD was $\pm 0.001 \mathrm{~K}$, which is similar to the overall resolution of the MTL. Additional weights were mounted on the upper part of the rod to increase penetration into the sediment. One MTL was mounted above the probe's weight and continuously measured the temperature in the water column (see Fig. 3a). As an example, Fig. 3b shows the temperatures recorded by the MTL during the deployment and penetration phase of station HF1702. In the first stage, the probe is lowered through the water column where we ran the MTLs in a simplified CTD mode to observe the water column temperatures. The sampling depths were then estimated from the winch speed and the MTL sampling rates. In the next phase the probe penetrates the sediment and peak temperatures are seen, due to the frictional heat. Furthermore, the frictional heat was an indicator that the individual sensors had entered the sediment. This could be also supported by a brief visual inspection of sediment coverage of the probe once it was hoisted back on deck. We used an up to 10 min steady-time, where the probe rests in the sediment, which allows for the frictional heat to decay and the temperatures to adjust to ambient sediment temperatures. Stage 3 is marked in red colors and highlights the stabilization of the sediment temperatures. The mean temperature of the stabilization phase is plotted against the depth below sea 


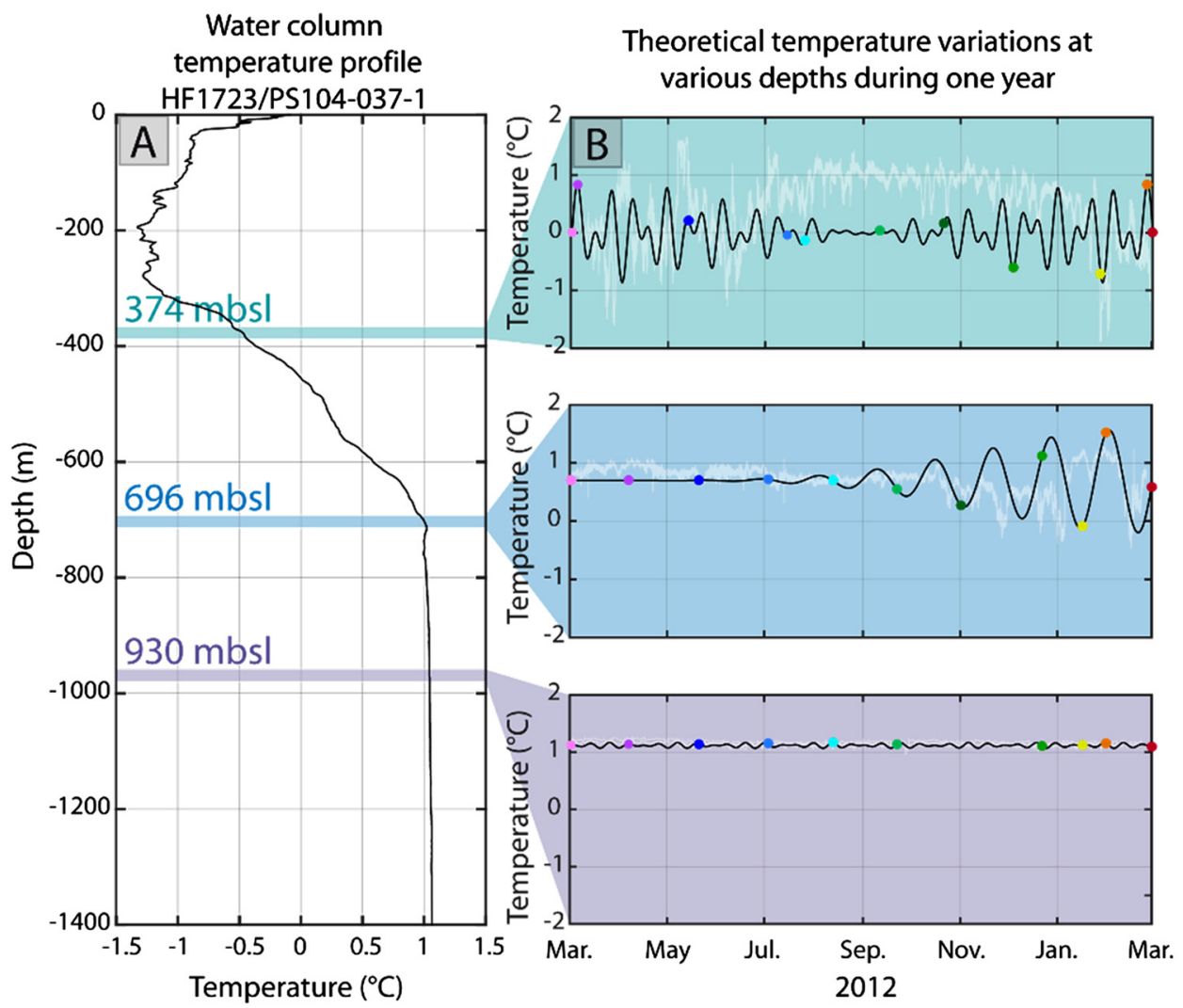

Theoretical temperature gradients in the sediment
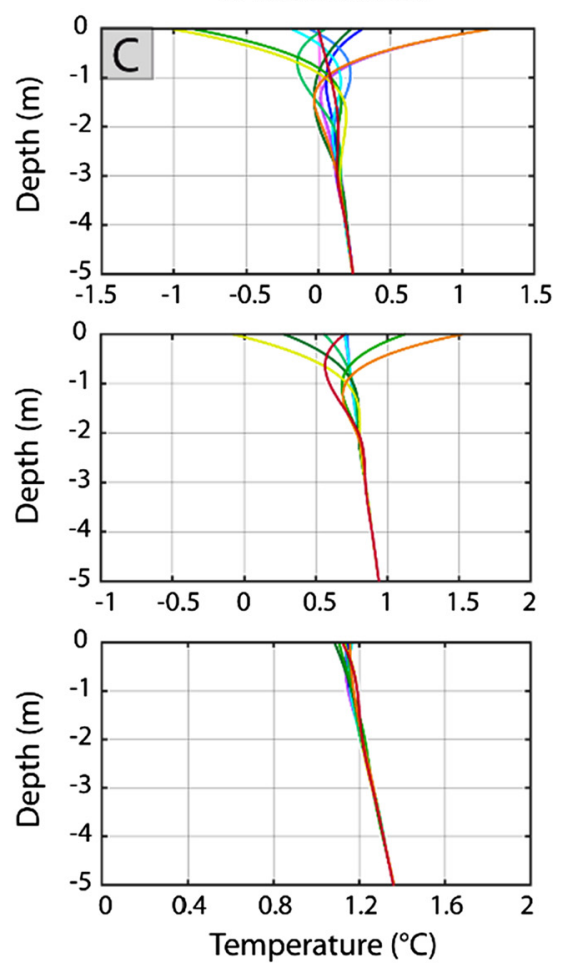

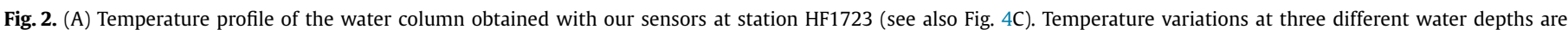

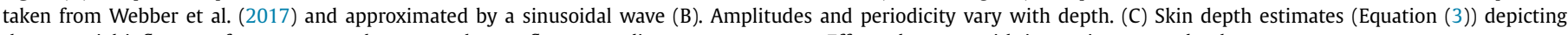
the potential influence of temperature changes at the sea floor on sediment temperatures. Effects decrease with increasing water depth.

floor of the sensors (see Fig. 3C). Because we do not have absolute depth information, we shift the sensors upwards until the uppermost sensor is at $z=0 \mathrm{~m}$ depth (sea floor) and calculate the thermal gradient with a linear fit. In the case of station HF1702, the sensor that penetrated less than $3 \mathrm{~m}$ into the sediment was not used for the linear regression to obtain the temperature gradient. The data collected at the 29 sites are shown in Supplement 1 according to the temperatures-depth profile described in Fig. 2c. At three sites in situ data could not be recovered because the probe either fell over (HF1707, HF1715), probably due to the stiffness of the sediment, or the logger was lost or damaged (HF1713). At stations HF1714 and HF1729, consolidated sediments likely prevented the entire penetration of the probe. We also attempted to measure temperature gradients in one of the MeBo seabed drill sites of this expedition (Gohl et al., 2017), but failed due to a stuck temperature downhole probe.

The thermal conductivity $(k)$ was measured on gravity cores taken in the vicinity of or at the sites shown in Supplement 2 with a KD2 Pro Thermal Property Analyzer that has an accuracy of $\pm 5 \%$ from 0.2 to $2 \mathrm{~W} \mathrm{~m}^{-1} \mathrm{~K}^{-1}$. The $6 \mathrm{~cm}$ long sensor applies a very small amount of heat to the needle, which helps to prevent free convection in liquid samples. Because of the sensor's heat pulse, a minimum of $1.5 \mathrm{~cm}$ of material parallel to the sensor in all directions was required to minimize errors. The sampling interval along the cores ranged between 10 and $20 \mathrm{~cm}$ (see Supplement 2). The thermal conductivity is temperature dependent and we corrected the influence of ambient laboratory temperatures $\left(\sim 20^{\circ} \mathrm{C}\right)$ by estimating the thermal conductivity at $4{ }^{\circ} \mathrm{C}$ via:

$k_{\text {sediment }\left(4{ }^{\circ} \mathrm{C}\right)}=\frac{k \cdot k_{\mathrm{Water}\left(4^{\circ} \mathrm{C}\right)}^{\varphi}}{k_{\mathrm{Water}\left(20^{\circ} \mathrm{C}\right)}^{\varphi}}$
This takes into account the porosity of the sediment $(\varphi \sim 0.65)$, the thermal conductivity of water at $20^{\circ} \mathrm{C}\left(k_{\text {Water }\left(20^{\circ} \mathrm{C}\right)}=0.6\right.$ $\left.\mathrm{W} \mathrm{mK}{ }^{-1}\right)$ and $4{ }^{\circ} \mathrm{C}\left(k_{\mathrm{Water}}\left(4^{\circ} \mathrm{C}\right)=0.57 \mathrm{~W} \mathrm{mK}^{-1}\right)$, respectively. The heat flow was calculated from the product of thermal conductivity $\left(k \sim 1.17 \mathrm{~W} \mathrm{mK}^{-1}\right)$ and temperature gradient (Table 1$)$.

\subsection{Analytical investigation of sediment temperature disturbances}

Heat flow determinations assume that heat is transported vertically in steady state, and thus require no lateral variations in surface boundary conditions or physical properties (Jaupart and Mareschal, 2007). The upper boundary condition of heat transfer in rocks or, as in this study's case, sediments is given by the temperatures at the sediment/water interface (sea floor) (Chouinard and Mareschal, 2007). If the subsurface (rocks or sediments) has been exposed to seasonal temperature variations or climate trends (warm-cold period), this signal is imprinted in the first few hundreds of meters. Examples are warming events in West Antarctica and the temporally changing warm CDW inflow onto the continental shelves (Hillenbrand et al., 2017). Diurnal or annual cycles can be typically seen in depths from a few centimeters to a couple of meters, whereas variations in the ground temperature of the last 200-300 years are recorded in the upper $200 \mathrm{~m}$. Surface temperature influence of post-glacial warming is observed down to $2500 \mathrm{~m}$. This is because surface temperature oscillations are damped over a length scale $\delta$ (skin depth)

$\delta=\sqrt{ } \kappa / 2 \omega$

which depends on their frequency $(\omega)$ and thermal diffusivity $(\kappa)$ (Carslaw and Jaeger, 1959). Borehole temperature depth profiles 

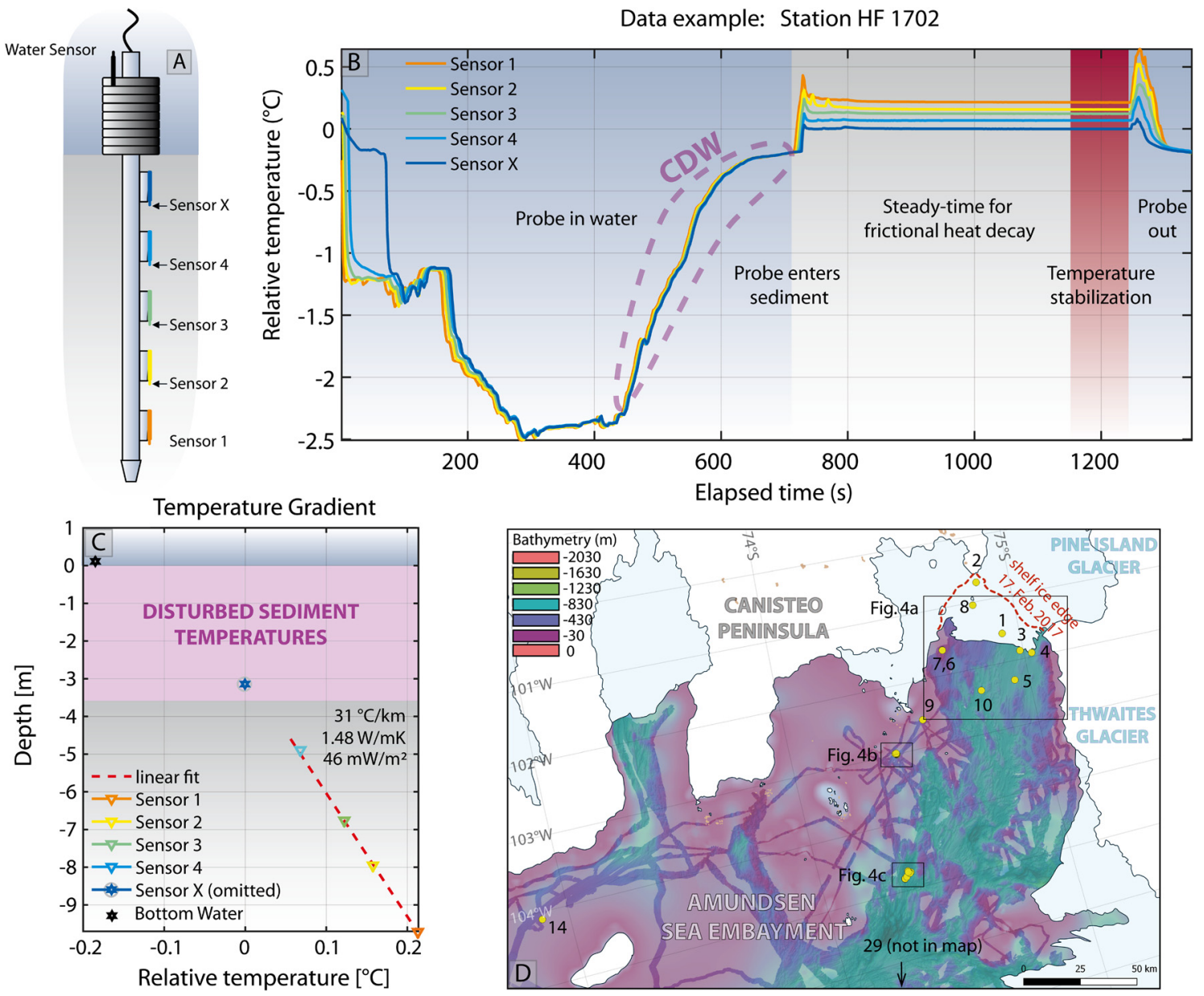

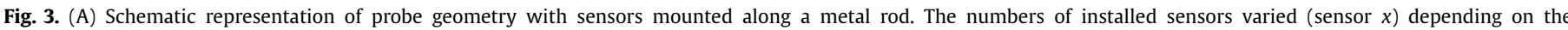

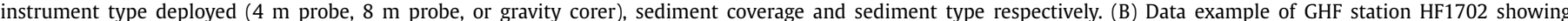

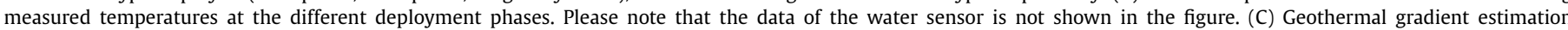

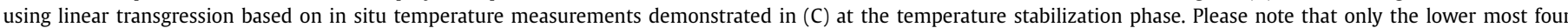

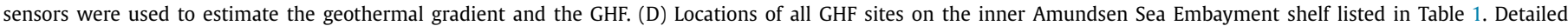
locations of sites with very high quality $\left({ }^{* * *}\right)$ are shown in Fig. 4.
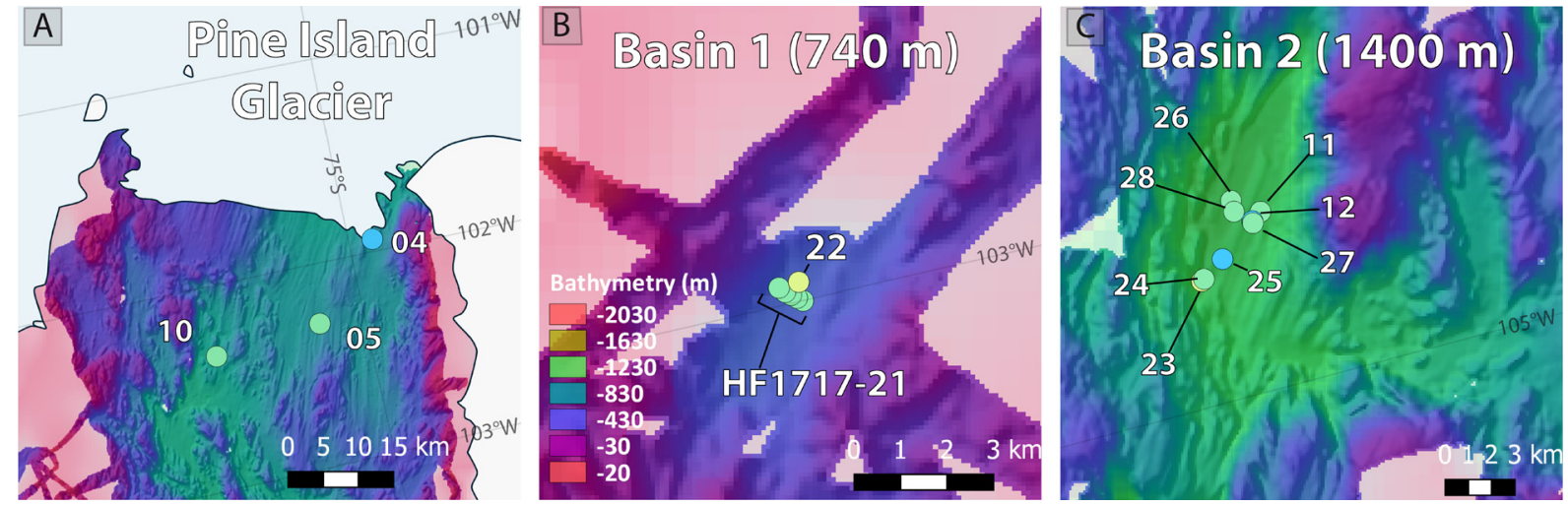

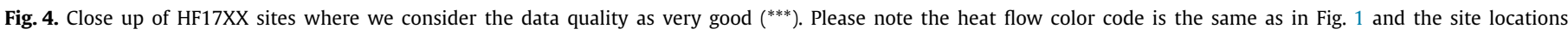

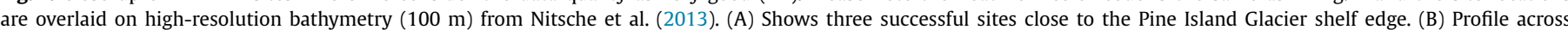
a small basin 1 at $\sim 740 \mathrm{mbsl}$ and $(\mathrm{C})$ in situ measurements in basin 2 at $1400 \mathrm{mbsl}$.

can therefore be used to reconstruct surface temperature variations on centennial time scales (Dahl-Jensen, 1998; Chouinard and Mareschal, 2007).

Long-term variations in atmospheric temperatures are similarly captured in large ice sheets. The original temperature signal, albeit dampened at their base, is still being observed (Engelhardt, 2004).
This can lead to spatial variations as high as $\pm 5^{\circ} \mathrm{C}$ at the bottom of an ice sheet.

A comparison of this dampening effect can be drawn to the marine environment, where ocean bottom currents influence the temperature profile of the underlying sediment (e.g. Müller et al., 2016; Dziadek et al., 2017). Müller et al. (2016) show that the large seasonal temperature variations $\left(>10^{\circ} \mathrm{C}\right)$ are dampened by 
$\sim 90 \%$ at depths of 3-5 m. The definition of sea floor temperatures requires consideration of long-term variations, such as the inflow of warmer CDW (e.g. Nakayama et al., 2013; Webber et al., 2017) and glacial melt water processes especially in the shallow regions of the ASE shelf. During deployment we monitored the temperature of the water column (see Fig. 2A and Fig. 3B) to observe the vertical temperature profile of the water column. This, however, only provides a snapshot at the time of our in situ measurements; it does not represent long-term changes, which likely disturb sediment temperatures. The iSTAR oceanographic mooring stations reveal multi-annual temperature variations with decreasing amplitudes and periodicities with depth (Webber et al., 2017) throughout the inner ASE shelf. Based on these observed signals we simulated temperature signals representing the variations at three different water depths: 374, 696 and 930 mbsl (see Fig. 2B). Since these depths represent our GHF sampling depths for the latter in situ temperature processing steps, we explored potential temperature distribution induced by such variations in the upper $5 \mathrm{~m}$ of the sediment. The analytical solution after Lowrie (1997) demonstrates the principal characteristics of sediment temperature changes induced by variations at the sea floor:

$T(z, t)=T_{\mathrm{BW}} \frac{d T}{d z} z e^{-\frac{z}{\delta}} \alpha \cos \left(\omega t-\frac{z}{\delta}\right)$

Temperature $T(z, t)$ is calculated as a function of depth $(z)$ and time $(t)$ for a homogeneous sediment and a constant background geothermal gradient $\left(d T d z^{-1}=0.0497^{\circ} \mathrm{Cm}^{-1}\right)$ which represents the measured average gradient in the ASE. We further measured a mean thermal diffusivity $\kappa\left(3.977 \mathrm{~mm}^{2} \mathrm{~s}^{-1}\right)$ on sediment cores that were taken during expedition PS104 (Supplement 2) and varied between 0.218 and $0.776 \mathrm{~mm}^{2} \mathrm{~s}^{-1}$. The multi-annual temperature variation in the water column of the ASE by Webber et al. (2017) (at a site at $106.535^{\circ} \mathrm{W} / 73.813^{\circ} \mathrm{S}$ ) reveal short periodic oscillations in temperature $\left( \pm 0.2^{\circ} \mathrm{C}\right)$ with maximum amplitudes of $\sim 1{ }^{\circ} \mathrm{C}$ with short periods. With our analytical solutions for different frequencies $\omega=\frac{2 \pi}{n}$ and $\frac{6 \pi}{n}\left(1 \mathrm{~s}^{-1} ; n=1 \mathrm{yr}\right)$ and amplitudes we explore the effects of three different scenarios: (1) long-period and high amplitude variations, which capture the largest temperature difference at the sea floor $\left(\Delta T=\sim 1^{\circ} \mathrm{C}\right)$ Webber et al. (2017) observed, (2) long-period and low amplitude variations, which as a first approximation reflect the periodicity observed by Webber et al. (2017), and (3) short period and low amplitude variations, which are likely to occur in shallow water depths (Fig. 2). On the basis of these simulations we would expect that long period oscillations $\left(< \pm 0.2^{\circ} \mathrm{C}\right)$ and the high frequency part of the temperature signal does not imprint in the sediment temperatures in deeper parts ( $>700 \mathrm{mbsl}$ ) of the inner ASE (see iSTAR A mooring at $930 \mathrm{mbsl}$ in Webber et al., 2017). The upper $3 \mathrm{~m}$ of the sediment column of the greater ASE shelf, however, very likely inherit bottom water temperature changes. Therefore, we do not use the upper most sensors that fall within this range for geothermal gradient determination. At sites with shallow penetration we however use the upper sensors.

\subsection{Considerations of further corrections}

Changes in topography can distort the temperature field and affect the heat flow estimate (Bullard, 1938). Bullard (1938) then demonstrated that no corrections to the measured temperature gradient need to be performed for shallow boreholes and flat topography. Thermal blanketing caused by sediment accumulation in basins of the inner Amundsen Sea Embayment shelf could further reduce geothermal surface heat flow by $5 \%$ (accumulation rates $100 \mathrm{~m} \mathrm{myrs}^{-1}$ ) and up to $20 \%$ (higher accumulation rates $500 \mathrm{~m} \mathrm{myrs}^{-1}$ ) for a thickness of the sedimentary layer up to 400 m (Davis et al., 1999; Hutnak and Fisher, 2007; Witus et al., 2014).

\section{Results}

\subsection{Geothermal heat flow}

The results of in-situ geothermal gradient measurements range between 8.6 and $97^{\circ} \mathrm{C} \mathrm{km}^{-1}$ and are presented in Table 1, with a confidence interval of $95 \%(2 \sigma)$. We used the mean thermal conductivity $\left(k=1.17 \mathrm{~W} \mathrm{mK}^{-1}\right)$, which was measured on gravity cores to estimate geothermal heat flow, which varies between 10.1 and $114.6 \mathrm{~mW} \mathrm{~m}^{-2}$. Based on our analytical solutions for theoretical temperature disturbances, penetration depth and water depth at the station, we introduce a data quality indicator (Table 1). High penetration, linear gradients and minor bottom water influence $(>800 \mathrm{mbsl}$ ) are marked with a very good quality indicator $\left({ }^{* *}\right)$, intermediate water depths $(600-800 \mathrm{mbsl})$ and/or fewer data points $(>2)$ to calculate the geothermal gradient are considered good data quality $\left(^{* *}\right)$ and shallow water depths $(<600 \mathrm{mbsl})$, low penetration and/or minimal data points (2) are considered as poor data quality $\left({ }^{*}\right)$. During the deployment at station HF1706 in close proximity to Pine Island Glacier (PIG), we mounted the MTLs onto the gravity corer and achieved higher penetration depths. Although most of the sensors were damaged during the deployment, we recovered data from two sensors ( 1.7 and $3.5 \mathrm{mbsf}$ ) that indicates a high gradient $\left(94.9^{\circ} \mathrm{C} \mathrm{km}^{-1}\right)$ and a resulting GHF $\left(\sim 111 \mathrm{~mW} \mathrm{~m}^{-2}\right)$. The uncertainties at this site however are large given the low sediment depth and expected temperature variations at the sea floor due to its shallow depth $(345 \mathrm{mbsl})$. A similar picture presents itself at station HF1714, where we measured $92.1^{\circ} \mathrm{C} \mathrm{km}^{-1}$. The overall data quality at this site is considered poor, because of shallow water depths $(490 \mathrm{mbsl})$ and therefore gradient disturbances caused by temperature variations at the sea floor and low penetration depths (1.9 mbsf).

\section{Discussion}

Our analysis reveals a spatially heterogeneous geothermal heat flow distribution on the ASE shelf. Towards Pine Island Glacier, estimates of highest GHF (Fig. 4B, HF1722: $76 \mathrm{~mW} \mathrm{~m}^{-2}$ ) correlate with a presumed volcanic heat production of the Hudson Mountain volcanic rocks and other subglacial volcanoes in their proximity, which have shown signs of recent activity (Corr and Vaughan, 2008). This potentially has implications for contemporary ice dynamics in the glacial system. Although Joughin et al. (2009) claim that local high GHF does not explain changes in basal conditions, it has been shown that the GHF from one subglacial volcanic center could produce enough basal meltwater to offset the basal energy balance and lubricate parts of an ice sheet bed that would otherwise remain frozen (Vogel and Tulaczyk, 2006). The measured data lie well within the range of GHF estimates for this region, which we present as probability density functions (PDF) in Fig. 5. Log-logistic PDFs are thought to realistically capture the small-scale GFH patterns (Shapiro and Ritzwoller, 2004) and were calculated with bin sizes of $2.5 \mathrm{~mW} \mathrm{~m}^{-2}$ for the region in West Antarctica. The broad distribution of GHF in various published studies is a result of the different methods and their limitations used. For example, the uncertainties in elastic and inelastic parameters for mantle minerals introduce uncertainties in temperatures inferred from seismic velocities (Shapiro and Ritzwoller, 2004). At depths deeper than $400 \mathrm{~km}$ compositional effects can lead to $\pm 100^{\circ} \mathrm{C}$ temperature change whereas uncertainties at depths shallower than $400 \mathrm{~km}$ range around $\pm 250^{\circ} \mathrm{C}$, assuming the seismic structure is well resolved, and composition known. Curie depth estimates, which capture a thermal signal in the crust 


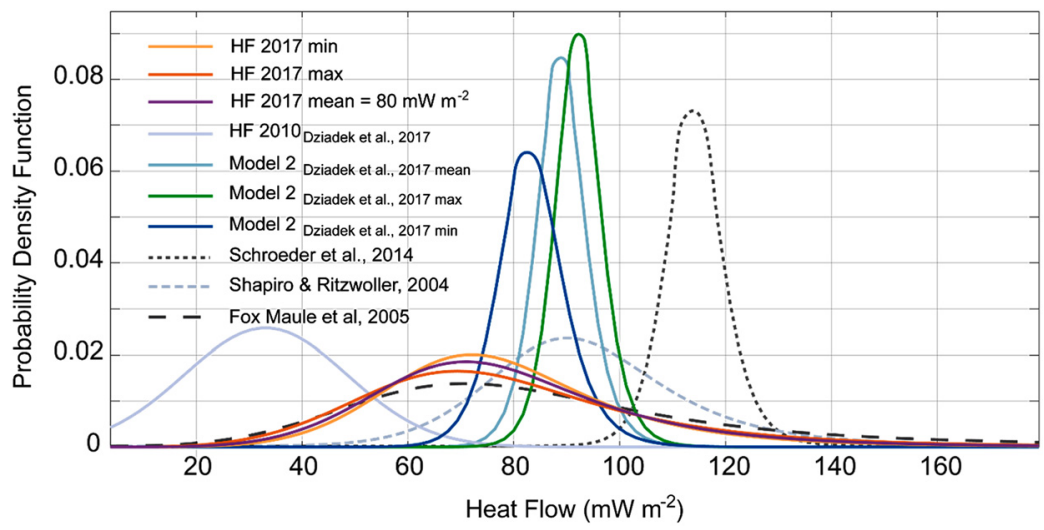

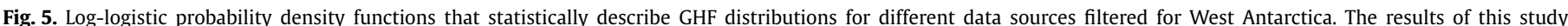

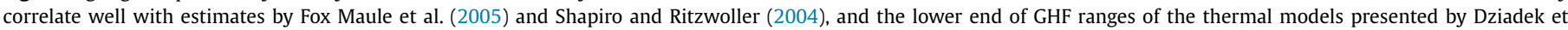
al. (2017).
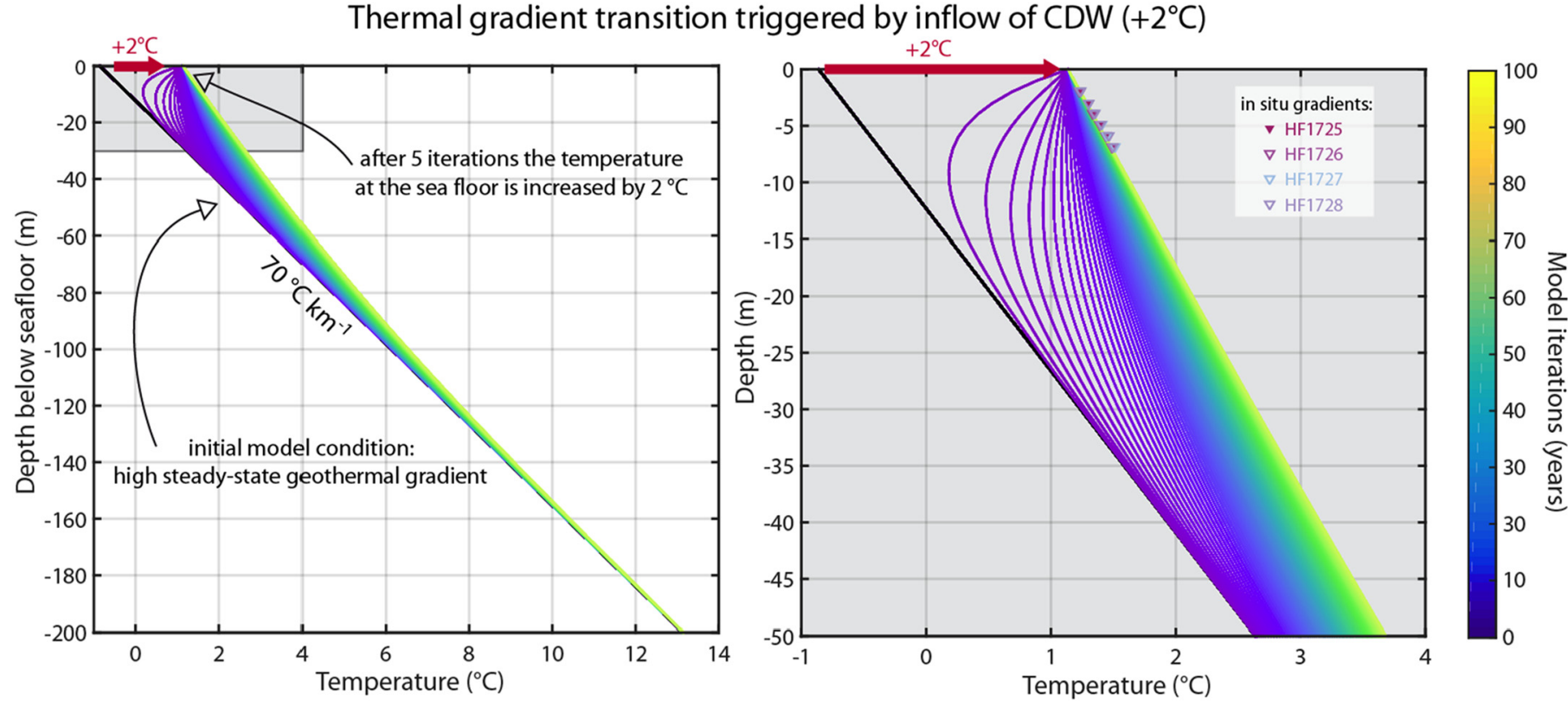

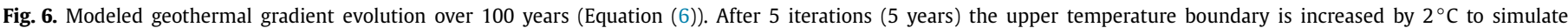

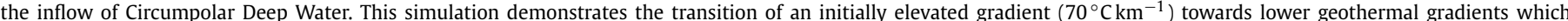

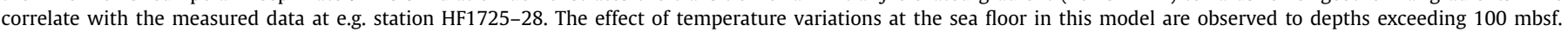

assume an homogeneous distribution of magnetic minerals, the main magnetic source being magnetite and thus with a Curie temperature of $580^{\circ} \mathrm{C}$ (Fox Maule et al., 2005; Dziadek et al., 2017; Martos et al., 2017). This assumption neglects the compositional variability in plutonic rocks that lead to Curie temperature ranges between $300^{\circ} \mathrm{C}$ and $680^{\circ} \mathrm{C}$, and in cases of magnetic assemblages of $\mathrm{Fe}-\mathrm{Ni}-\mathrm{Co}-\mathrm{Cu}$ metal alloys up to $620^{\circ} \mathrm{C}$ to $1084^{\circ} \mathrm{C}$ (Haggerry, 1978). Without further constraints and validations these assumptions remain our best guess, especially in sparsely sampled regions like Antarctica, but introduce uncertainties of several kilometers in Curie Depths and hence GHF estimates. The distribution of inferred GHF values presented in Dziadek et al. (2017) at the lower range of distributions shown in Fig. 5 is attributed to the biases implied by the sampling strategy imposed by the temperature probe length and the variability in bottom water temperatures.

\section{CDW induced gradient transition}

In this study, we consider the effect of the warmer CDW on geothermal gradients by exploring the geotherm transitions ana- lytically. Fourier's law for heat diffusion is derived by a statement for the conservation of energy

$\rho c_{p} \frac{\delta T}{\delta t}=-\nabla^{\mathrm{T}} q+s=-\left[\frac{\delta}{\delta x} \frac{\delta}{\delta y}\right]\left[\begin{array}{l}q_{x} \\ q_{y}\end{array}\right]+s$

and a general anisotropic constitutive relationship

$q=\left[\begin{array}{l}q_{x} \\ q_{y}\end{array}\right]=-\left[\begin{array}{ll}k_{x x} & k_{x y} \\ k_{y x} & k_{y y}\end{array}\right]\left[\begin{array}{c}\frac{\delta}{\delta x} \\ \frac{\delta}{\delta y}\end{array}\right] T=-D \nabla T$

to yield:

$\rho c_{p} \frac{\delta T}{\delta t}=-\nabla^{\mathrm{T}}(D \nabla T)+s$

This equation (e.g. Crank, 1975) governs transient heat conduction in two-dimensions with a source term $s(x, y)$, the dependent variable is temperature $T$, the independent variables time $t$ and distance $x$ and $k_{i j}(x, y)$ are the components of the thermal conductivity tensor, $\rho(x, y)$ is density and $c_{p}(x, y)$ is heat capacity. We determined numerical finite element method (FEM) solutions 
of equation (6) for geothermal gradients to illustrate the potential thermal gradient transitions if the temperature at the sea floor increased by $2{ }^{\circ} \mathrm{C}$ (Fig. 6). The mixed evidence and limited historical data make it difficult to pinpoint the onset of CDW inflow onto the Amundsen shelf (Jacobs and Comiso, 1997). The driver for changes in CDW delivery to Pine Island Bay on decadal time scales is linked to stronger westerly winds over the Southern Ocean (Thoma et al., 2008; Hillenbrand et al., 2017). This strong atmospheric variability is thought to be influenced by, for example warm (El Niño) conditions in the central Pacific, which might have increased CDW incursion as early as the early 1940s (Schneider and Steig, 2008; Hillenbrand et al., 2017; Jenkins et al., 2017). We therefore investigate a thermal gradient transition over 100 years with initial conditions of an elevated geothermal gradient $\left(70^{\circ} \mathrm{C} \mathrm{km}^{-1}\right)$ in thermal steady-state condition. After 5 iterations ( 5 years) the temperature at the sea floor $(z=0)$ is increased by $2{ }^{\circ} \mathrm{C}$ to simulate the inflow of warm CDW. This model shows, that a gradient transition towards lower gradients fits our observed gradients, for example at stations HF1725-HF1728. Hypothetically this implies that our results represent transient geothermal heat flow and might be biased towards lower values. The sparsity of the available data however does not provide a basis for any further reasonable corrections. Although this is beyond the scope of this study, our water column snap shots (Supplement 3) could help tune models for simulated bottom potential temperatures, especially when attempting to resolve ice-ocean interaction for small ice shelves in regions such as the Amundsen Sea Embayment (e.g. Assmann et al., 2013; Nakayama et al., 2014).

\section{Conclusion}

Newly acquired GHF measurements extend existing datasets in the Amundsen Sea Embayment (Dziadek et al., 2017). After careful examination of potential disturbances in sediment temperatures induced by variations of bottom water temperatures, we conclude the following: The temperature distribution of the water column on the Amundsen Sea shelf is strongly variable, hence we use examples for our analytical solutions and not only in situ data, as they do not cover the entire sampling area. Sediments in shallow parts $(<350 \mathrm{~m})$ of the shelf are likely to be exposed to stronger, annual $\left(\Delta T=\sim 1{ }^{\circ} \mathrm{C}\right.$ ) temperature variations leading to larger errors in GHF estimates. Decadal dynamics of the ambient water temperature at the sea floor cannot be neglected either when collecting geothermal gradient data at shallow depths. In the wider sense, for any scenario, for instance gradient measurements below the ice sheet, the knowledge of thermal history at the bed rock-ice interface is critical for accurate estimates. We improved the temperature processing method described by Dziadek et al. (2017) for a 2010 campaign in the ASE, where in situ temperature measurements in shallow critical depths were not considered. We discussed hypothetical gradient transitions, which yield implications for the observations and models of the visco-elastic response of the lithosphere in the broader Amundsen Sea sector. High, nonuniform uplift rates due to recent ice-mass changes (Groh et al., 2012) could be linked to high geothermal gradients, which in turn have potential influence on the understanding of the ice sheet dynamics in the region. The mean estimated geothermal heat flow of $65 \mathrm{~mW} \mathrm{~m}^{-2}$ is likely a result of CDW overprinting and thermal blanketing by sedimentary processes, particularly within the basins since the last glacial maximum. These processes could cause a reduction of up to $20 \%$ of the GHF. By correcting for this factor, the GHF would range between $65 \mathrm{~mW} \mathrm{~m}^{-2}$ and $95 \mathrm{~mW} \mathrm{~m}^{-2}$. In parts of the WARS, however, where sediments are almost entirely absent, we would suspect, that GHF values might lie well above our measured estimates. This would have crucial significance for models long-term ice sheet dynamics and related sea level rise predic- tions. The results of this study also show the increasing need to drill onshore and offshore for collecting deeper in situ temperatures, which are less exposed to surface temperature variations.

\section{Acknowledgements}

This work was supported by the Deutsche Forschungsgemeinschaft (DFG) in the framework of the Priority Program 1158 "Antarctic research with comparative investigations in Arctic ice areas" by grant GO 724/14-1. Additional funds were contributed by the AWI Research Program PACES-II Workpackage 3.2. The study contributes to the Scientific Program "Past Antarctic Ice Sheet Dynamics" (PAIS) of the Scientific Committee for Antarctic Research (SCAR). Many thanks to the Crew of RV Polarstern expedition PS104 (2017) for their support, endless engagement and creative thinking in unforeseen situations. We thank Fausto Ferraccioli and an anonymous reviewer for the constructive comments, which benefited the manuscript considerably. The data sets collected for this study will be available at PANGAEA database (www.pangea.de) after publication.

\section{Appendix A. Science Team of Expedition PS104}

\begin{tabular}{ll}
\hline Name, First Name & Organization \\
\hline Gohl, Karsten & AWI \\
Uenzelmann-Neben, Gabriele & AWI \\
Hochmuth, Katharina & AWI \\
Riefstahl, Florian & AWI \\
Dziadek, Ricarda & AWI \\
Gebhardt, Catalina & AWI \\
Arndt, Jan-Erik & AWI \\
Klages, Johann & AWI \\
Esper, Oliver & AWI \\
Ronge, Thomas & AWI \\
Küssner, Kevin & AWI \\
*Kuhn, Gerhard & AWI \\
Larter, Robert & BAS \\
Hillenbrand, Claus-Dieter & BAS \\
Smith, James & BAS \\
Bickert, Torsten & MARUM \\
Pälike, Heiko & MARUM \\
Frederichs, Thomas & MARUM \\
Freudenthal, Tim & MARUM \\
Zundel, Maximilian & U Bremen \\
*Spiegel, Cornelia & U Bremen \\
Ehrmann, Werner & U Leipzig \\
Bohaty, Steve & NOCS UK \\
van de Flierdt, Tina & Imperial UK \\
Simões Pereira, Patric & Imperial/BAS \\
Najman, Yani & Lancaster Univ \\
Scheinert, Mirko & TU Dresden \\
Ebermann, Benjamin & TU Dresden \\
Afanasyeva, Victoria & VNIIOkean, Russia \\
\hline
\end{tabular}

* Onshore.

\section{Appendix B. Supporting information}

Supporting information related to this article can be found online at https://doi.org/10.1016/j.epsl.2018.11.003.

\section{References}

Assmann, K.M., Jenkins, A., Shoosmith, D.R., Walker, D.P., Jacobs, S.S., Nicholls, K.W., 2013. Variability of circumpolar deep water transport onto the Amundsen Sea Continental shelf through a shelf break trough. J. Geophys. Res., Oceans 118 (12), 6603-6620. https://doi.org/10.1002/2013JC008871.

Barletta, V.R., et al., 2018. Observed rapid bedrock uplift in Amundsen Sea Embayment promotes ice-sheet stability. Science 360 (6395), 1335-1339. https:// doi.org/10.1126/science.aao1447. 
Begeman, C.B., Tulaczyk, S.M., Fisher, A.T., 2017. Spatially variable geothermal heat flux in West Antarctica: evidence and implications. Geophys. Res. Lett. 44 (19), 9823-9832. https://doi.org/10.1002/2017GL075579.

Bullard, E.C., 1938. The disturbance of the temperature gradient in the Earth's crust by inequalities of height. Geophys. J. Int. 4 (4), 360-362. https://doi.org/10.1111/ j.1365-246X.1938.tb01760.x.

Burton-Johnson, A., Halpin, J.A., Whittaker, J.M., Graham, F.S., Watson, S.J., 2017. A new heat flux model for the Antarctic Peninsula incorporating spatially variable upper crustal radiogenic heat production. Geophys. Res. Lett. 44 (11), 5436-5446. https://doi.org/10.1002/2017GL073596.

Carslaw, H.S., Jaeger, J.C., 1959. Conduction of Heat in Solids, 2nd ed. Oxford University Press, London.

Chaput, J., Aster, R.C., Huerta, A., Sun, X., Lloyd, A., Wiens, D., Nyblade, A., Anandakrishnan, S., Winberry, J.P., Wilson, T., 2014. The crustal thickness of West Antarctica. J. Geophys. Res., Solid Earth 119 (1), 378-395. https://doi.org/10. 1002/2013JB010642.

Chen, B., Haeger, C., Kaban, M.K., Petrunin, A.G., 2017. Variations of the effective elastic thickness reveal tectonic fragmentation of the Antarctic lithosphere. Tectonophysics. https://doi.org/10.1016/j.tecto.2017.06.012.

Chouinard, C., Mareschal, J.-C., 2007. Selection of borehole temperature depth profiles for regional climate reconstructions. Clim. Past 3 (1), 121-163. https:// doi.org/10.5194/cpd-3-121-2007.

Corr, H.F.J., Vaughan, D.G., 2008. A recent volcanic eruption beneath the West Antarctic ice sheet. Nat. Geosci. 1 (2), 122-125. https://doi.org/10.1038/ngeo106.

Crank, J., 1975. The Mathematics of Diffusion, second ed. Oxford University Press, Uxbridge.

Dahl-Jensen, D., 1998. Past temperatures directly from the Greenland Ice Sheet. Science 282 (5387), 268-271. https://doi.org/10.1126/science.282.5387.268.

Dalziel, I.W.D., Lawver, L.A., 2001. The Lithospheric Setting of the West Antarctic Ice Sheet.

Damiani, T.M., Jordan, T.A., Ferraccioli, F., Young, D.A., Blankenship, D.D., 2014. Variable crustal thickness beneath Thwaites Glacier revealed from airborne gravimetry, possible implications for geothermal heat flux in West Antarctica. Earth Planet. Sci. Lett. 407, 109-122. https://doi.org/10.1016/j.epsl.2014.09.023.

Davies, J.H., 2013. Global map of solid Earth surface heat flow. Geochem. Geophys. Geosyst. 14 (10), 4608-4622. https://doi.org/10.1002/ggge.20271.

Davis, E.E., Chapman, D.S., Wang, K., Villinger, H., Fisher, A.T., Robinson, S.W., Grigel, J., Pribnow, D., Stein, J., Becker, K., 1999. Regional heat flow variations across the sedimented Juan de Fuca Ridge eastern flank: constraints on lithospheric cooling and lateral hydrothermal heat transport. J. Geophys. Res. 104 (4), 17675. https://doi.org/10.1029/1999JB900124.

Decker, E.R., Bucher, G.J., 1982. Geothermal studies in the Ross Island-Dry Valley region. In: Craddock, C. (Ed.), Antarctic Geoscience, vol. 4. University of Wisconsin Press, Madison, pp. 887-894

Dziadek, R. Gohl, K., Diehl, A. Kaul, N., 2017. Geothermal heat flux in the Amundsen Sea sector of West Antarctica: new insights from temperature measurements, depth to the bottom of the magnetic source estimation, and thermal modeling. Geochem. Geophys. Geosyst. 18 (7), 2657-2672. https://doi.org/10.1002/ 2016GC006755.

Engelhardt, H., 2004. Ice temperature and high geothermal flux at Siple Dome, West Antarctica, from borehole measurements. J. Glaciol. 50 (169), 251-256. https:// doi.org/10.3189/172756504781830105.

Fisher, A.T., Mankoff, K.D., Tulaczyk, S.M., Tyler, S.W., Foley, N., the WISSARD Science Team, 2015. High geothermal heat flux measured below the West Antarctic Ice Sheet. Sci. Adv. 1 (6), e1500093. https://doi.org/10.1126/sciadv.1500093.

Fox Maule, C., Purucker, M.E., Olsen, N., Mosegaard, K., 2005. Heat flux anomalies in Antarctica revealed by satellite magnetic data. Science 309 (5733), 464-467. https://doi.org/10.1126/science.1106888.

Gohl, K., et al., 2017. MeBo70 seabed drilling on a polar continental shelf: operational report and lessons from drilling in the Amundsen Sea Embayment of West Antarctica. Geochem. Geophys. Geosyst. 18 (11), 4235-4250. https:// doi.org/10.1002/2017GC007081.

Golledge, N.R., Kowalewski, D.E., Naish, T.R., Levy, R.H., Fogwill, C.J., Gasson, E.G.W., 2015. The multi-millennial Antarctic commitment to future sea-level rise. Nature 526 (7573), 421-425. https://doi.org/10.1038/nature15706.

Gow, A.J., Ueda, H., Garfield, D., 1968. Antarctic Ice Sheet: preliminary results of the first core to bedrock. Science 161 (3845), 1013-1101.

Groh, A., Ewert, H., Scheinert, M., Fritsche, M., Rülke, A., Richter, A., Rosenau, R., Dietrich, R., 2012. An investigation of Glacial Isostatic Adjustment over the Amundsen Sea sector, West Antarctica. Glob. Planet. Change 98-99, 45-53. https://doi.org/10.1016/j.gloplacha.2012.08.001.

Haggerry, S.E., 1978. Mineralogical constraints on Curie isotherms in deep crustal magnetic anomalies. Geophys. Res. Lett. 5 (2), 105-108.

Hillenbrand, C.D., et al., 2017. West Antarctic Ice Sheet retreat driven by Holocene warm water incursions. Nature 547 (7661), 43-48. https://doi.org/10.1038/ nature22995.

Hughes, T., 2009. Modeling ice sheets from the bottom up. Quat. Sci. Rev. 28 (19-20), 1831-1849. https://doi.org/10.1016/j.quascirev.2009.06.004.

Hutnak, M., Fisher, A.T., 2007. Influence of sedimentation, local and regional hydrothermal circulation, and thermal rebound on measurements of seafloor heat flux. J. Geophys. Res., Solid Earth 112 (12), 1-19. https://doi.org/10.1029/ 2007JB005022.

Hyndman, R.D., Currie, C.A., Mazzotti, S., Frederiksen, A., 2009. Temperature contro of continental lithosphere elastic thickness, Te vs Vs. Earth Planet. Sci. Lett. 277 (3-4), 539-548. https://doi.org/10.1016/j.epsl.2008.11.023.

Jacobs, S.S., Comiso, J.C., 1997. Climate variability in the Amundsen and Bellinghausen seas. J. Climate 10 (4), 697-709. https://doi.org/10.1175/15200442(1997)010<0697:CVITAA>2.0.CO;2.

Jaupart, C., Mareschal, J.-C., 2007. Heat flow and thermal structure of the lithosphere. In: Schubert, G. (Ed.), Treatise on Geophysics. Elsevier, Amsterdam, pp. 217-252.

Jenkins, A., Dutrieux, P., Jacobs, S., Steig, E., Gudmundsson, H., Smith, J., Heywood, K. 2017. Decadal ocean forcing and Antarctic Ice Sheet response: lessons from the Amundsen Sea. Oceanography 29 (4), 106-117. https://doi.org/10.5670/oceanog. 2016.103.

Joughin, I., Tulaczyk, S., Bamber, J.L., Blankenship, D., Holt, J.W., Scambos, T. Vaughan, D.G., 2009. Basal conditions for Pine Island and Thwaites Glaciers, West Antarctica, determined using satellite and airborne data. J. Glaciol. 55 (190), 245-257. https://doi.org/10.3189/002214309788608705.

Kalberg, T., Gohl, K., Eagles, G., Spiegel, C., 2015. Rift processes and crustal structure of the Amundsen Sea Embayment, West Antarctica, from 3D potential field modelling. Mar. Geophys. Res. 36 (4), 263-279. https://doi.org/10.1007/s11001015-9261-0.

LeMasurier, W.E., 2008. Neogene extension and basin deepening in the West Antarc tic rift inferred from comparisons with the East African rift and other analogs. Geology 36 (3), 247-250. https://doi.org/10.1130/G24363A.1.

Llubes, M., Lanseau, C., Rémy, F., 2006. Relations between basal condition, subglacial hydrological networks and geothermal flux in Antarctica. Earth Planet. Sci. Lett. 241 (3-4), 655-662. https://doi.org/10.1016/j.epsl.2005.10.040.

Lowrie, W., 1997. Fundamentals of Geophysics. Cambridge University Press, Campridge.

Martos, Y.M., Catalán, M., Jordan, T.A., Golynsky, A., Golynsky, D., Eagles, G., Vaughan, D.G., 2017. Heat flux distribution of Antarctica unveiled. Geophys. Res. Lett. 44 (22), 11,417-11,426. https://doi.org/10.1002/2017GL075609.

McKenzie, D., 1978. Some remarks on the development of sedimentary basins. Earth Planet. Sci. Lett. 40 (1), 25-32. https://doi.org/10.1016/0012-821X(78)90071-7.

Morgan, P., 1983. Constraints on rift thermal processes from heat flow and uplift Dev. Geotecton. 19 (C), 277-298. https://doi.org/10.1016/B978-0-444-42198-2. 50023-7.

Morin, R.H., Williams, T., Henrys, S.A., Magens, D., Niessen, F., Hansaraj, D., 2010 Heat flow and hydrologic characteristics at the AND-1B borehole, ANDRILL McMurdo Ice Shelf Project, Antarctica. Geosphere 6 (4), 370-378. https://doi org/10.1130/GES00512.1.

Müller, C., Usbeck, R., Miesner, F., 2016. Temperatures in shallow marine sediments: influence of thermal properties, seasonal forcing, and man-made heat sources. Appl. Therm. Eng. 108, 20-29. https://doi.org/10.1016/j.applthermaleng.2016.07. 105.

Nakayama, Y., Schröder, M., Hellmer, H.H., 2013. From circumpolar deep water to the glacial meltwater plume on the eastern Amundsen Shelf. Deep-Sea Res., Part 1, Oceanogr. Res. Pap. 77, 50-62. https://doi.org/10.1016/j.dsr.2013.04.001.

Nakayama, Y., Timmermann, R., Schröder, M., Hellmer, H.H., 2014. On the difficulty of modeling Circumpolar Deep Water intrusions onto the Amundsen Sea continental shelf. Ocean Model. 84, 26-34. https://doi.org/10.1016/j.ocemod.2014.09. 007.

Nicholls, K.W., Paren, J.G., 1993. Extending the Antarctic meteorological record using ice-sheet temperature profiles. J. Climate 6, 141-150.

Nitsche, F.O., Gohl, K., Larter, R.D., Hillenbrand, C.D., Kuhn, G., Smith, J.A., Jacobs, S. Anderson, J.B., Jakobsson, M., 2013. Paleo ice flow and subglacial meltwater dynamics in Pine Island Bay, West Antarctica. Cryosphere 7 (1), 249-262. https:// doi.org/10.5194/tc-7-249-2013.

Pfender, M., Villinger, H., 2002. Miniaturized data loggers for deep sea sediment temperature gradient measurements. Mar. Geol. 186, 557-570.

Pollack, H.N., Hurter, S.J., Johnson, J.R., 1993. Heat flow from the Earth's interior: analysis of the global data set. Rev. Geophys. 31 (3), 267-280. https://doi.org 10.1029/93RG01249.

Price, P.B., Nagornov, O.V., Bay, R., Chirkin, D., He, Y., Miocinovic, P., Richards, A. Woschnagg, K., Koci, B., Zagorodnov, V., 2002. Temperature profile for glacial ice at the South Pole: implications for life in a nearby subglacial lake. Proc. Natl. Acad. Sci. 99 (12), 7844-7847. https://doi.org/10.1073/pnas.082238999.

Purucker, M.E., 2012. Geothermal heat flux data set based on low resolution observations collected by the CHAMP satellite between 2000 and 2010, and produced from the MF-6 model following the technique described in Fox Maule et al. (2005). https://core2.gsfc.nasa.gov/research/purucker/heatflux_updates.html. (Accessed 22 January 2018).

Risk, G.F., Hochstein, M.P., 1974. Heat flow at arrival heights, Ross Island, Antarctica. N.Z. J. Geol. Geophys. 17 (3), 629-644. https://doi.org/10.1080/00288306.1973. 10421586.

Rogozhina, I., Hagedoorn, J.M., Martinec, Z., Fleming, K., Soucek, O., Greve, R., Thomas, M., 2012. Effects of uncertainties in the geothermal heat flux distribution on the Greenland Ice Sheet: an assessment of existing heat flow models. J. Geophys. Res., Earth Surf. 117 (2), 1-16. https://doi.org/10.1029/2011JF002098. 
Schneider, D.P., Steig, E.J., 2008. Ice cores record significant 1940s Antarctic warmth related to tropical climate variability. Proc. Natl. Acad. Sci. 105 (34), 12154-12158. https://doi.org/10.1073/pnas.0803627105.

Schroeder, D.M., Blankenship, D.D., Young, D.A., Quartini, E., 2014. Evidence for elevated and spatially variable geothermal flux beneath the West Antarctic Ice Sheet. Proc. Natl. Acad. Sci. 111 (25), 9070-9072. https://doi.org/10.1073/pnas. 1405184111.

Seroussi, H., Ivins, E.R., Wiens, D.A., Bondzio, J., 2017. Influence of a West Antarctic mantle plume on ice sheet basal conditions. J. Geophys. Res., Solid Earth 122 (9), 7127-7155. https://doi.org/10.1002/2017JB014423.

Shapiro, N., Ritzwoller, M.H., 2004. Inferring surface heat flux distributions guided by a global seismic model: particular application to Antarctica. Earth Planet. Sci. Lett. 223 (1-2), 213-224. https://doi.org/10.1016/j.epsl.2004.04.011.

Siegert, M.J., 2000. Antarctic subglacial lakes. Earth-Sci. Rev. 50, 29-50.

Siegert, M.J., Dowdeswell, J.A., 1996. Spatial variations in heat at the base of the Antarctic ice sheet from analysis of the thermal regime above subglacial lakes. J. Glaciol. 42 (142), 501-509. https://doi.org/10.1017/S0022143000003488.

Thoma, M., Jenkins, A., Holland, D., Jacobs, S., 2008. Modelling Circumpolar Deep Water intrusions on the Amundsen Sea continental shelf, Antarctica. Geophys. Res. Lett. 35 (18). https://doi.org/10.1029/2008GL034939.
Della Vedova, B., Pellis, G., Lawver, L.A., Brancolini, G., 1992. Heat flow and tectonics in the western Ross Sea. In: Yoshida, Y. (Ed.), Recent Progress in Antarctic Earth Science. Terra Scientific Publishing Company, Tokyo, pp. 627-637.

Vogel, S.W., Tulaczyk, S., 2006. Ice-dynamical constraints on the existence and impact of subglacial volcanism on West Antarctic ice sheet stability. Geophys. Res. Lett. 33 (23), 2-5. https://doi.org/10.1029/2006GL027345.

Webber, B.G.M., Heywood, K.J., Stevens, D.P., Dutrieux, P., Abrahamsen, E.P., Jenkins, A., Jacobs, S.S., Ha, H.K., Lee, S.H., Kim, T.W., 2017. Mechanisms driving variability in the ocean forcing of Pine Island Glacier. Nat. Commun. 8, 1-8. https:// doi.org/10.1038/ncomms14507.

Witus, A.E., Branecky, C.M., Anderson, J.B., Szczuciński, W., Schroeder, D.M., Blankenship, D.D., Jakobsson, M., 2014. Meltwater intensive glacial retreat in polar environments and investigation of associated sediments: example from Pine Island Bay, West Antarctica. Quat. Sci. Rev. 85, 99-118. https://doi.org/10.1016/j. quascirev.2013.11.021.

Zagorodnov, V., Nagornov, O., Scambos, T.A., Muto, A., Mosley-Thompson, E., Pettit, E.C., Tyuflin, S., 2012. Borehole temperatures reveal details of 20th century warming at Bruce Plateau, Antarctic Peninsula. Cryosphere 6 (3), 675-686. https://doi.org/10.5194/tc-6-675-2012. 